\title{
Dry Ports Development: A Pivot Strategy to Enhance Sustainable Transit Traffic via West African Corridors
}

\author{
By Sewodo Augustin Degbe ${ }^{*} \&$ Bingliang Song ${ }^{\dagger}$
}

\begin{abstract}
West Africa like many other regions in Africa, is enjoying a period of rapid growth in the past decade and within this period, its international trade has grown significantly. However, the region lacks sufficient dry ports, which can enhance a sustainable transportation of transit cargoes via the various corridors as well as relieving pressures on the seaports. The essence of this paper is to select an optimum location for the development of a dry port in West Africa based on specific factors relevant to the research objective. The center of gravity location model was applied at the landside in order to ascertain the transportation cost of goods from selected coastal ports to the hinterland markets as well selecting an optimum location for the development of dry port with a cost minimization objective. A simple forecast of demand throughput for West African landlocked countries was also applied using time series regression analysis in order to access the traffic growth rate as well as the associated capacity constraints that the ports might experience in the nearest future. Finally, SWOT analysis was used to analyze the endogenous and exogenous factors, which are deemed crucial to the development of dry port in selected West African Country.
\end{abstract}

Keywords: Dry Port, Landlocked Countries (LLCs), Transit Traffic, West Africa.

\section{Introduction}

Dry port development has received great attention from numerous scholars recently and its emergence is regarded as a prime outcome of the continuous increase in containerization and the growing integration between seaports and hinterland networks (Nguyen et al. 2016). As seaports' transport volume continues to grow, inland access becomes a critical factor for the seaports' competitive advantage. Thus, a progressive operation at the maritime sector and the seaport terminals without any developments in inland access by means of intermodalism is not sufficient for the whole transportation chain to function (Roso et al. 2009). The ability for countries to deliver goods and services on time and at the lowest possible cost is a key determinant of integration into the world economy today and landlocked developing countries in West Africa continue to face serious constraints and challenges in the areas of trade, transit, and overall socio-economic development. Unfortunately, just as traffic continues to grow through the transport corridor by each passing year, so are the difficulties in managing the trade.

The United Nations Convention on the Law of the Sea (UNCLOS) defined a

*PhD Student, Shanghai Maritime University, China.

${ }^{\dagger}$ Professor, Shanghai Maritime University, China. 
landlocked country as a "state or country without any access to the sea" and the permission by a coastal country for hinterland nations to transit through its seaport(s) is a permissible right. West Africa consists of twelve coastal countries with ports of relatively significant scale of operations and three landlocked countries (Burkina-Faso, Mali \& Niger). Additionally, six out of the twelve coastal states provide substantial transit traffic services to the hinterland countries thus, regional corridors are predominantly important to hinterland nations because they serve as economic lifelines providing the only overland paths to global and regional markets.

\section{Problem Statement}

As business environment becomes more competitive and global than ever, service industries such as ports, are placing greater emphasis on customer satisfaction through providing quality services efficiently (Song and Cullinane 1999). The World Bank Logistics Performance Index (LPI) which is an overall LPI score measures the performance of a country's logistics based on efficiency of arranging competitive shipments in terms of price, quality of logistics services, ability to track and trace consignments, and frequency with which shipments reach the consignee within the scheduled time (Arvis et al. 2014). According to this index, Germany, Luxembourg and Sweden are the most efficient and highly ranked LPI countries at positions 1, 2 and 3 in the 2016 LPI. In Africa, South Africa, Kenya and Egypt are the most consistent and highly ranked in logistics performance at 20,42 and 49 positions respectively. West African countries had mixed rankings with Burkina-Faso ranked the highest at position 81 followed by Ghana, Nigeria, Togo, Cote d'Ivoire and Niger which are ranked at 86, 90, 92, 95 and 100 positions respectively. How then can the development of a dry port improve the transportation network by enhancing sustainable transit traffic which would reduce the total transport and logistics cost within the region? This research intends to unveil some comprehensive analysis which would serve as a unique tool for strategic decision making.

\section{Research Objectives}

The main objective of this research is to ascertain an optimum location where dry port(s) can be sited in West Africa and its economic impact on transit traffic designated for West African Landlocked countries. In order to achieve this goal, this study intends to address other supporting objectives which are considered crucial to the research. These objectives include; highlighting the principal factors influencing the development of dry ports, factors influencing the growth of transit traffic, hinterland transportation cost analysis for West African landlocked countries and to identify the endogenous and exogenous factors in developing a dry port in West Africa. 


\section{Literature Review}

\section{Dry Port Concept}

The concept of dry ports became global in conjunction with containerization. Dry Port or Inland Clearance Depot (ICD) can be defined as: "A common user facility with public authority status, equipped with fixed installations and offering services for handling and temporary storage of any kind of goods (including containers) carried under customs transit by any applicable mode of transport, placed under customs control and with customs and other agencies competent to clear goods for home use, warehousing, temporary admissions, re-export, temporary storage for onward transit and outright export" (UNESCAP 2012).

\section{Drivers behind the Emergence and Development of Dry Ports}

Veenstra et al. (2012) ascertained that the usage of inland transport nodes has become more pragmatic considering the fact that every organization has its own individual objectives for developing dry ports. Major drivers behind the development of dry ports include; sustainable access to hinterland locations, constraints at the seaports and a means to facilitating economic zones which are considered nodes in the supply chain. Several gateway ports are currently confronted with development limitations such as diseconomies of scales, environmental issues and land availability (Roso 2005). Considering these restrictions, most seaports have delve into the development of dry ports as a solution to relieve burdens while improving in the operations through a modal slip. Thus, relocating space consuming activities to inland locations. An example of this scenario is the port of Genoa in Italy (Caballini and Gattorna 2009). Additionally, another reason for developing dry ports is to gain a competitive position through the expansion of hinterland connectivity network.

\section{Dry Port Classification and Functions}

Dry Ports are located based on their assessment criteria, need and the center of gravity favorable to the shippers. Nevertheless, dry port development should be evaluated with its cost functions and also value added services that can be provided to every stakeholder in the logistics network. Roso et al. (2009) categorized inland nodes as close, mid-range \& distance dry ports (Figures 1-3) and this classification has been used by numerous scholars in their works. In general, dry port plays a role of operations by rail or road to and from serving ports customs clearance, warehousing with temporary storage of cargo and containers and computerized processing of documents. Dry ports can also be sited in different location based on its distance to the seaport and the three types of geographical location of dry port also plays different role. A summary of these categories and functions is buttressed in Table 1.

The main role of close dry ports is to relieve the seaports from the burden of space shortage, congestion and environmental issues. With abundant land 
available, all high space-consuming activities, such as warehousing or sorting, are shifted from seaports to dry ports. The customs clearance procedures could be carried out in these close dry ports.

Figure 1. A Seaport with a Close Dry Port

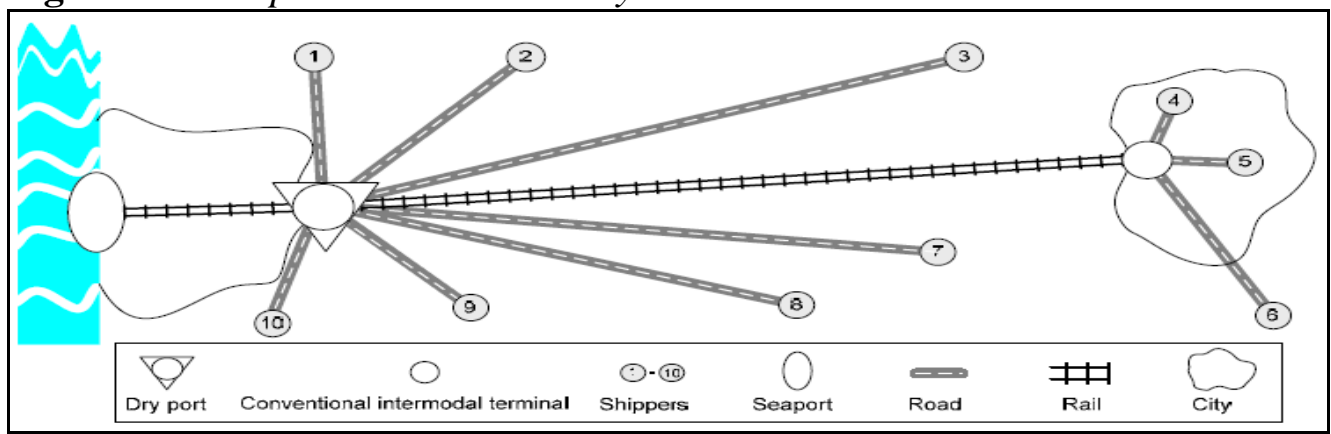

Source: Woxenius et al. (2004) The Dry Port Concept - Connecting Seaports with their Hinterland by Rail, p. 11.

Mid-range dry port functions as a consolidation center for diverse rail services, denoting technical and administrative equipment define for sea transport. It works as inter-modal centers to consolidate or deconsolidate cargo from shippers. It can also function as a trans-modal/trans-loading terminal before cargoes are being transported to their designated markets. These types of dry ports are more beneficial to the seaports because it increases the hinterland access in getting close to customers. Pollution and congestions are also tackled by the implementation of modal shift from trucks to barges/trains.

Figure 2. A Seaport with Mid-Range Dry Port

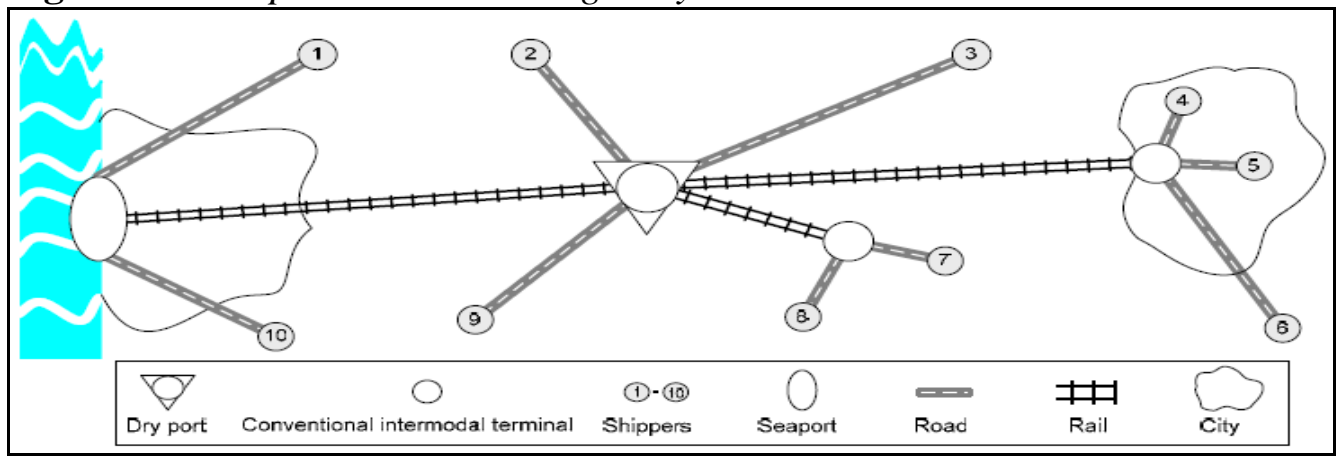

Source: Woxenius et al. (2004) The Dry Port Concept - Connecting Seaports with their Hinterland by Rail, p. 10 .

The distant dry port is situated near the market, which might be the consuming area in import-based supply chains, or a core production location in export-based supply chains. This type of dry port plays an imperative role in the logistics system of landlocked countries to connect to international markets. In this case, the seaport will benefit from the connection to this type of dry port by gaining access to the inland market. 
Figure 3. A Seaport with a Distant Dry Port

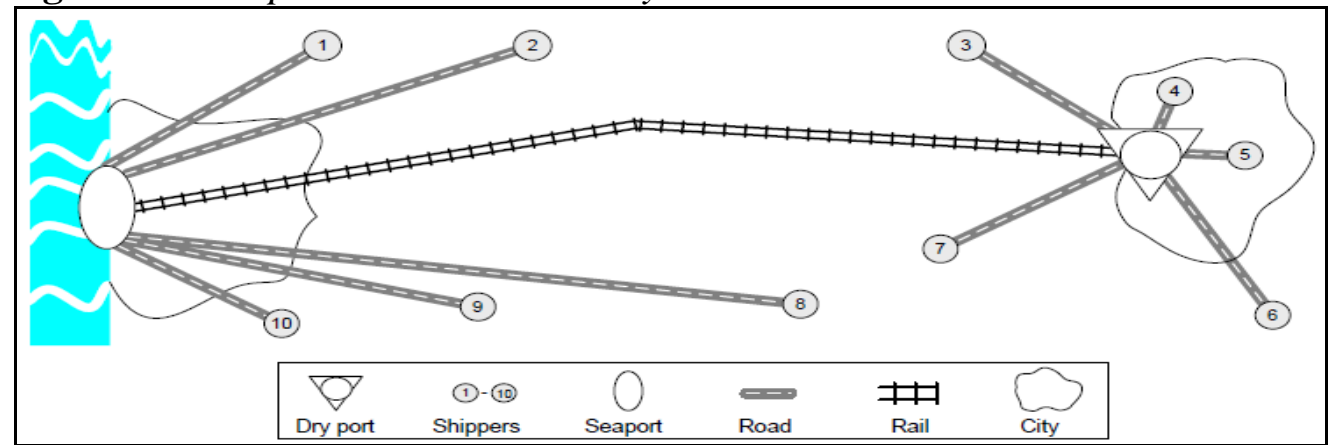

Source: Woxenius et al. (2004) The Dry Port Concept - Connecting Seaports with their Hinterland by Rail, p. 8 .

Table 1. Dry Port Categories and their Functions

\begin{tabular}{|l|l|l|l|}
\hline & \multicolumn{1}{|c|}{$\begin{array}{c}\text { Close dry port/ } \\
\text { satellite terminal }\end{array}$} & $\begin{array}{c}\text { Mid-range dry } \\
\text { port/ transloading } \\
\text { center }\end{array}$ & $\begin{array}{c}\text { Distant dry port/load } \\
\text { center }\end{array}$ \\
\hline $\begin{array}{l}\text { Development } \\
\text { reason }\end{array}$ & Seaport constraints & Hinterland access & $\begin{array}{c}\text { Economic zone } \\
\text { facilitation }\end{array}$ \\
\hline $\begin{array}{l}\text { Position in } \\
\text { hinterland } \\
\text { supply chain }\end{array}$ & Start Point & Middle point & End point \\
\hline $\begin{array}{l}\text { Development } \\
\text { driver }\end{array}$ & $\begin{array}{c}\text { Sea-driven } \\
\text { (Outside-in) }\end{array}$ & Sea or land driven & \multicolumn{1}{|c|}{$\begin{array}{l}\text { Land driven } \\
\text { (inside out) }\end{array}$} \\
\hline Role & $\begin{array}{l}\text { - Relieve seaports } \\
\text { from space shortage, } \\
\text { congestion \& } \\
\text { environmental issues. } \\
\text { - Handling cargo } \\
\text { - Custom Clearance } \\
\text { - Low value added } \\
\text { service }\end{array}$ & $\begin{array}{l}\text { - Transmodal } \\
\text {-Tranloading } \\
\text { cargoes } \\
\text { - Modal shift } \\
\text { - Consolidation \& } \\
\text { deconsolidation } \\
\text {-Value added } \\
\text { services }\end{array}$ & $\begin{array}{l}\text { - Distribution } \\
\text { - Consolidation for } \\
\text { exported cargo } \\
\text { - Reduce congestion } \\
\text { - Modal Shift } \\
\text {-High value added } \\
\text { services }\end{array}$ \\
\hline
\end{tabular}

Source: Nguyen C. L., Notteboom T. (2006) Dry Ports as Extensions of Maritime Deep-Sea Ports, p. 69.

\section{Container Terminal Capacity}

Container Terminal Capacity (CTC) has recently emerged as a foremost problem in several ports around the globe. Capacity measures are generally in units of output per time period and must signify the maximum throughput possible unimpeded by demand or other schemes: maximum crane moves per hour/day, TEU/acre, maximum TEU per hour/day/year and yard storage. Capacity problem happens when the input is larger than the probable output that can be produced by a terminal. Liu (2010) clarified that due to negative procedure variation in the sub-structural efficiency, excess or congestion has become a serious problem. Therefore, container port volume should be able to 
handle the fast-tracking pace of demand in emergent economies and thus, it is the traffic development that energizes the expansion of ports' capacity. Some scholars have shown an intense apprehension about how to handle capacity problem. For example, Liu (2010) ascertain that terminals and container ports are obliged to cope with overcapacity because it has a substantial feature that indicates how dependable and significant the port relates to stakeholders and thus, it is important in defining traffic. Maloni and Jackson (2005) classify container capacity influence as endogenous and exogenous port capacity factors. The endogenous port capacity measures include technology, capital, waterways, labor, facilities, equipment, and efficiency while the exogenous port capacity dynamics include shipper efficiency, railroad truck capacity and efficiency, steamship line efficiency, capacity and efficiency, road congestion and OTI (Ocean Transportation Intermediaries) efficiency.

\section{Solutions to the Container Terminal Capacity Issue}

Conferring to Nguyen and Notteboom (2016) the following measures are proposed as solutions to container terminal capacity.

- Physical Expansion

- Using Automation and new technologies

- Improving the utilization of resources

- Floating and dry docks

- Investing in dry ports

\section{Potential Benefits of a Dry Port}

Some foremost benefits of developing dry port are elaborated with more collaboration with inland localities which will foster an increase in regional productivity using a more efficient and effective connection with inland transport nodes and stronger support for the cargo handling operation of the port because of adequate use of land space and augmented possibilities for a fruitful modal shift. Additionally, there is a development of the hinterland, and likelihood to capture a larger market share as competing ports as well as retaining customers in the hinterland markets. Other benefits are better understanding and level of service in the remote markets; increased prospects for intermodal services, even on shorter distances, more eye-catching hinterland services are offered because of an increased reliability, frequency and flexibility which will further reinforce the geographic concentration of logistics firms, thus, creating benefits for both seaports, inland terminals; and a more basic customs procedures.

\section{Summary of Reviewed Literatures}

Literatures concerning the study have been reviewed and it is undisputed that numerous outstanding studies have been conducted in the domain of dry port development but very few of these articles cover the West African sector. 
There are numerous port expansion projects going on within the region. Therefore, there is a need for more substantial research to be conducted in order to address transport related problems that the region might be confronted with in the nearest future. Additionally, none of the studies reviewed have assessed political risk and the recent pirate attacks on the gulf of guinea as factors that can influence the development of dry port in West Africa.

\section{Methodology}

\section{Transport Corridor Concept}

The notion of "corridor" is not a new phenomenon, as this has existed for centuries ago. The ancient Silk Road is probably the best-known transit corridor globally, one that has had an enduring impact on the social and economic development on the expanses it crossed Kunaka and Carruthers (2014). Although the notion lacks an exact definition because of it physical and functional dimensions, it is generically understood to synchronize bundle of logistics and transport frameworks and services that accelerates trade and transportation which flows between centers of economic activities. A simple objective of a corridor project(s) include optimizing infrastructure connectivity, facilitating the efficient transit flow of freight and promoting economic growth by refining the effectiveness of exports commodities and reducing imports costs or emerging clusters of economic frameworks along the corridor strip supported by efficient and effective logistics systems (Arnold 2005). Additionally, a corridor is typically governed by national or regional body which constitute of a public or private sectors or an amalgamation of both.

\section{Major Transit Corridors in West Africa}

According to a report issued by Danida consulting group on Accelerating Trade in West Africa (Danida-Saana 2015), West African corridors can be categorized into "transit corridors and intra- regional corridors". In West Africa, transit corridors include; (1) Lagos ${ }^{1}(\mathrm{NG})$ - Jibiya the frontier with Niger and beyond (2) Cotonou (BN) - Niamey (NG), (3) Lomé (TG) - Ouagadougou (BF), (4) Tema (GH) - Ouagadougou (BF), (5) Abidjan (CI) - Ouagadougou (BF), (6) Abidjan (CI) - Bamako (ML), (7) San Pedro (CI) - Bamako (ML), (8) Conakry (GN) - Bamako, (ML) and (9) Dakar (SN) - Bamako (ML). The two principal West-East intra-regional transit corridors existing in the zone are; (10) Dakar, (SN) - Niamey, (NE) and (11) Dakar, (SN) - Lagos, (NG). These principal routes emanates from six major port cities; Abidjan-Cote d'Ivoire; Cotonou-Benin; Dakar-Senegal; Lagos-Nigeria (with three ports Apapa, Tin Can and Lekki); Lomé-Togo and Tema-Ghana (See Figure 4). Additionally, all corridors serve bilateral trade between ECOWAS member states as well as international trade. In

${ }^{1}(\mathrm{NG})$-Nigeria, (BN)-Benin Republic, (NG)-Niger, (TG)-Togo, (BF)-Burkina-Faso, (GH)-Ghana, (CI)-Cote-d'Ivoire, (ML)-Mali, (GN)-Guinea, (SN)-Senegal, (NE)-Niamey. 
particular, they connect the three hinterland nations (Burkina-Faso, Mali and Niger) with coastal countries and market outside the region.

Figure 4. Map of West Africa Indicating Major Transit Corridors

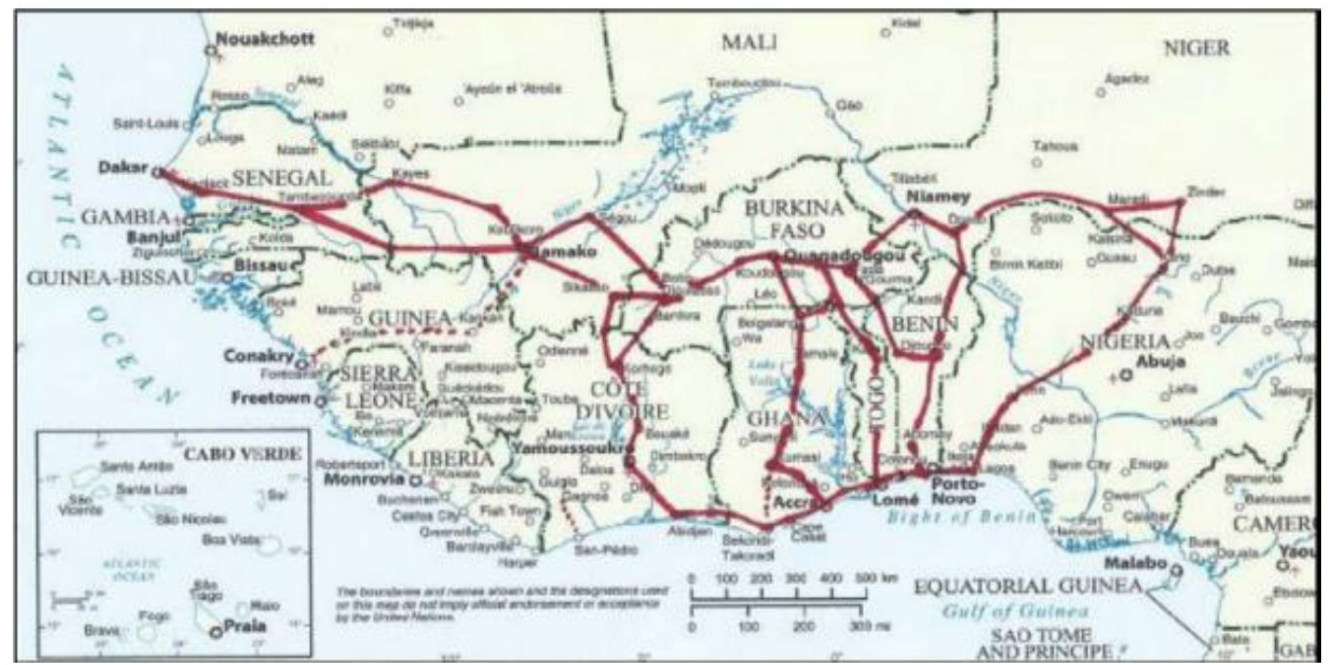

Source: Torres and Van Seters (2016), p. 24.

Factors Influencing the Growth of Transit Traffic in West Africa

The African continent is amid a transformative change and this will absolutely have a positive impact on its populations and thus increasing its market dimension. By 2020, Africa will have an approximated population of 2.1 billion people and a collective GDP of US\$2.6 trillion and this is because the continent remains a minerals treasure house and it has about $60 \%$ of the world's uncultivated arable land. Additionally, the West African region is at the heart of Africa's economic transformation with a growth rate of $6.0 \%$ in 2014 (AFDB 2015). The dynamics enumerated below are considered as the major factors influencing the growth of transit trade in West Africa;

i. Sustainable Economic Growth: The averaged Africa's GDP growth was 5\% from 2002 to 2012 and it is expected to significantly increase by $5.5 \%$ in 2018 which is higher than any other region except Asia and this has put Africa above America and Europe. Better economic sector accompanied with economic growth has tremendously improved its governance systems, lower foreign debt, lower inflation and lower budget deficit hence making African economies more resilient than in the past (CNBC Africa 2017).

ii. Implementation of Legal Instruments by Regional Bodies and Bilateral Transit Trade between Member Countries: Regional Trade Agreements (RTAs) in West Africa are basically in form of Free Trade Agreements (FTAs) and to a minimal extent Preferential Trade Agreements (PTAs) and the custom unions have been a principal façade of the global multilateral trading systems (see 
iii. Table 2 2). Within Sub-Saharan Africa, RTAs have principally involved nations belonging to a specific sub-region (i.e. "natural trading partners"). The main RECs in Sub-Saharan Africa are; Economic Community of West African States (ECOWAS), Economic Community of Central African States (ECCAS), West African Economic and Monetary Union (WAEMU), East African Community (EAC), Intergovernmental Authority on Drought and Development (IGADD) and Southern Africa Development Corporation (SADC).

Table 2. Bilateral Trade Agreements between Landlocked and Transit Countries in $W / A$

\begin{tabular}{|c|c|c|c|c|c|c|}
\hline \multirow{2}{*}{ W/A } & \multicolumn{5}{|c|}{ Selected West African Coastal Countries with Seaports } \\
\cline { 2 - 7 } LLC's & Benin & Cote d'Ivoire & Ghana & Nigeria & Senegal & Togo \\
\hline B. Faso & $\mathrm{a}, \mathrm{b}, \mathrm{c}$ & $\mathrm{a}, \mathrm{b}, \mathrm{c}, \mathrm{d}$ & $\mathrm{a}, \mathrm{b}, \mathrm{c}$ & N/A & $\mathrm{a}, \mathrm{b}, \mathrm{c}$ & $\mathrm{a}, \mathrm{b}, \mathrm{c}$ \\
\hline Mali & $\mathrm{a}, \mathrm{b}, \mathrm{c}$ & $\mathrm{a}, \mathrm{b}, \mathrm{c}$ & N/A & N/A & $\mathrm{a}, \mathrm{b}, \mathrm{c}, \mathrm{d}$ & $\mathrm{a}, \mathrm{b}, \mathrm{c}$, \\
\hline Niger & $\mathrm{a}, \mathrm{b}, \mathrm{c}, \mathrm{d}$ & $\mathrm{a}, \mathrm{b}, \mathrm{c}$ & N/A & $\mathrm{a}, \mathrm{b}, \mathrm{c}$ & $\mathrm{a}, \mathrm{b}, \mathrm{c}$ & $\mathrm{a}, \mathrm{b}, \mathrm{c}$ \\
\hline
\end{tabular}

$\mathrm{a}=$ port agreement, $\mathrm{b}=$ transit agreement, $\mathrm{c}=$ road transport agreement, $\mathrm{d}=$ rail transport agreement.

Source: N'Guessan (2013) and Danida-Saana (2016).

iv. Port Infrastructure Development: Many African countries are tremendously investing in port infrastructures in order to meet growing demand and improve port performance and major international container operators are also eager to invest. New road and rail networks as well as the expansions at airports and harbors are also under construction so as to assist trade, while substantial capital investments which are internationally financed have demonstrated the strengths in these economies (AFDB 2010). Nearly three million containers were transported in West Africa in 2015 and this is quite a significant figure for the West African region.

v. Implementation of Joint Cross-Border Initiative: There is currently an ongoing optimism that the novel methodology to regionalization will have bigger success in Africa. An example of this novel methodology is the Regional Integration Facilitation Forum (RIFF) which originated as a Cross-Border Initiative (CBI) in 1992. The objective of this framework is to harmonize policies that can foster a market-driven concept of integration between Southern and Western Africa and the Indian Ocean countries. About fourteen member countries are active participants in the CBI/RIFF and it is co-sponsored by the European Union (EU), International Monetary Fund (IMF), African Development Bank (ADB), and the World Bank.

\section{Port Selection Alternatives for Shippers in West African LLC's}

This study takes into account three LLCs (Burkina-Faso, Mali, Niger) and six ports (Abidjan, Cotonou, Dakar, Lagos, Lomé \& Tema) (see Figure 5); hence, a combination of 18 alternatives (See Table 6). The capitals of the three hinterland countries have also been considered as the major center of commercial activities; 
namely, Bamako, Niamey and Ouagadougou. Additionally, the various transport infrastructure and intermodal transport is explained in Table 3 while a pictorial view is provided in Figure 6.

Figure 5. LLCs' Shippers Port Selection Alternatives in West Africa

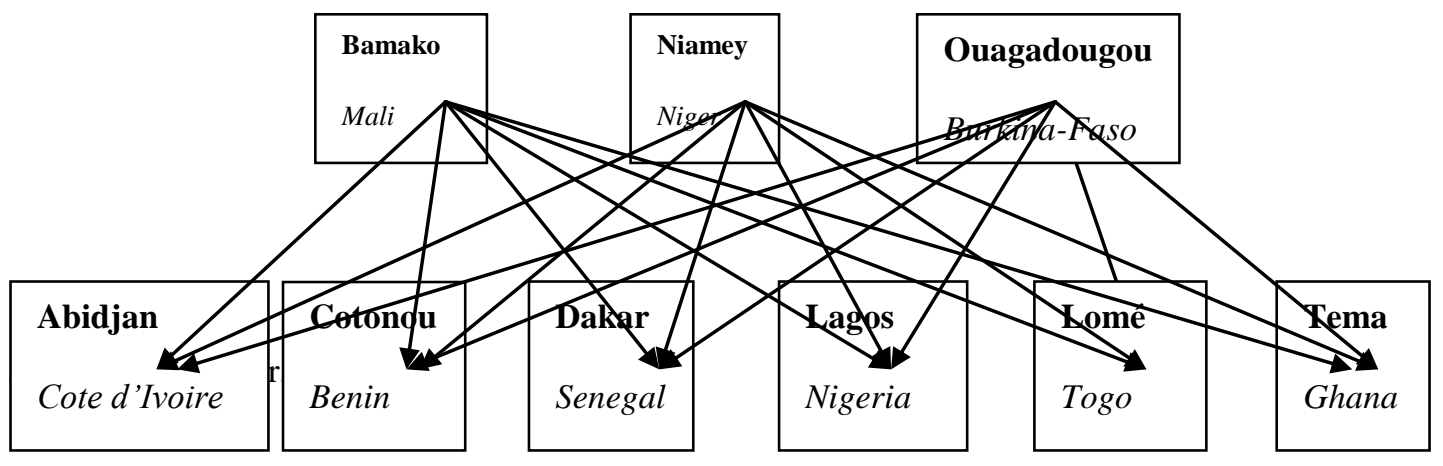

Table 3. Transport Infrastructure in Selected West African Ports

\begin{tabular}{|c|c|c|c|c|}
\hline $\begin{array}{c}\text { Transport } \\
\text { Infrastructure }\end{array}$ & $\begin{array}{c}\text { Rail } \\
\text { Facilities }\end{array}$ & $\begin{array}{c}\text { Rail } \\
\text { Management }\end{array}$ & $\begin{array}{l}\text { Road } \\
\text { Access }\end{array}$ & Road Traffic Condition \\
\hline Benin & Yes & N/A & Yes & congestion in port area \\
\hline Cote d'Ivoire & Yes & $\begin{array}{l}\text { SITARAIL - } \\
\text { Bolloré/APMT }\end{array}$ & Yes & congestion in port area \\
\hline Ghana & Yes & N/A & Yes & Congestion on access road \\
\hline Nigeria & No & N/A & Yes & $\begin{array}{l}\text { congestion in port area and } \\
\text { exit points }\end{array}$ \\
\hline Senegal & Yes & $\begin{array}{c}\text { Senegal+Mali } \\
+ \\
\text { Transrail }\end{array}$ & Yes & Congestion at port exit points \\
\hline Togo & Yes & Togo-Rail & Yes & $\begin{array}{c}\text { No Congestion at port but on } \\
\text { roads }\end{array}$ \\
\hline
\end{tabular}

Source: Debrie (2012) and Researchers' Field Data (2018).

Figure 6. Rail and Road Links in West Africa

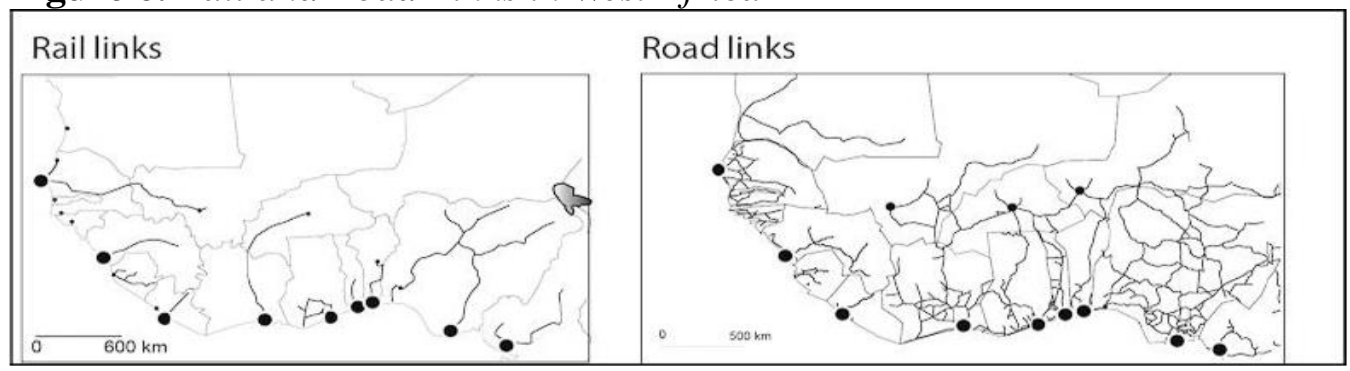

Source: Debrie (2012). The West African Port System.

Hinterland Transportation Cost Analysis for West African Countries

In this section, the total transport cost from various coastal ports to the different hinterland markets was analyzed, and this is because they remain the commercial centers in the LLC's. In total, six scenarios were analyzed per each major port location and the transport cost determined. The distances of various 
locations of the commercial centers was used in part to determine the attractiveness of each proposed alternative port with regards to cost minimization for inland transport to key hinterland markets. The method takes into account the location of the coastal ports and markets, the shipping costs in US\$ per ton kilometer and the volume of goods shipped or to be shipped to those locations (volume of imports and exports). The real road distances from ports to markets are used in this part of the study and the objective here is cost minimization. Hence, the port-market route that offers the least cost to transit traffic would be preferred by shippers in LLC's.

\section{Data Analysis}

The demand for each location is the sum of imports and exports in million tons. From Table 4, it can be observed that Mali recorded the highest tonnage of cargo in 2016 by 7.31 million tons and this was followed by Burkina-Faso and Niger which recorded 6.9 and 5.72 million tons of cargo respectively in 2016.

Table 4. Demand (Imports and Exports) Data for West African LLC (Million Tons)

\begin{tabular}{|c|c|c|c|c|c|c|c|c|c|c|c|}
\hline \multirow{2}{*}{ Country } & \multicolumn{10}{|c|}{ Year } \\
\cline { 2 - 13 } & 2006 & 2007 & 2008 & 2009 & 2010 & 2011 & 2012 & 2013 & 2014 & 2015 & 2016 \\
\hline B-Faso & 1.87 & 2.26 & 2.60 & 2.28 & 3.31 & 4.76 & 5.52 & 5.99 & 5.77 & 6.33 & 6.90 \\
\hline Mali & 3.90 & 4.54 & 4.82 & 3.78 & 4.76 & 5.11 & 5.89 & 5.99 & 6.06 & 6.46 & 7.31 \\
\hline Niger & 1.58 & 1.78 & 2.26 & 2.79 & 3.11 & 3.46 & 3.34 & 3.60 & 3.94 & 5.21 & 5.72 \\
\hline
\end{tabular}

Source: Researchers' extraction from various ports website and PMAWCA, 2017.

Transport costs in ton $\mathrm{km}$ are represented in Table 5, Cote d'Ivoire and Ghana enjoys the cheapest transport cost of 0.17 US\$ per ton km with Dakar recording the highest with 0.21 US\$ per ton $\mathrm{km}$. The pricing mechanism for such transport in West Africa is based on the cost of fuel along with road conditions, indirect costs and direct costs associated with inland transportation.

Table 4. Average Transport Cost (US\$/ton km. kilometer)

\begin{tabular}{|l|c|c|}
\hline Country & $\begin{array}{c}\text { Transport cost }- \text { road } \\
\text { (US\$ ton km) }\end{array}$ & $\begin{array}{c}\text { Transport cost }- \text { rail } \\
\text { (US\$ ton km) }\end{array}$ \\
\hline Benin & 0.18 & N/A \\
\hline Cote d'Ivoire & 0.17 & 0.14 \\
\hline Ghana & 0.17 & N/A \\
\hline Nigeria & 0.20 & N/A \\
\hline Senegal & 0.21 & 0.18 \\
\hline Togo & 0.18 & N/A \\
\hline
\end{tabular}

Source: Borderless West Africa 2016.

Corridor distances were derived from Sofreco and Nathan Associates and the distances range from about $928 \mathrm{~km}$ from Lomé - Ouagadougou and $3250 \mathrm{~km}$ for the Dakar-Lagos corridor. 
Table 5. Distances between Selected Transit Corridors in W/A

\begin{tabular}{|c|c|c|}
\hline Countries & Corridors & Distances $(\mathrm{Km})$ \\
\hline \multirow{5}{*}{ Benin } & Cotonou - Bamako & 1947 \\
\hline & Cotonou - Niamey & 1070 \\
\hline & Cotonou - Ouagadougou & 1200 \\
\hline & Cotonou-Lagos & 126 \\
\hline & Cotonou-Lomé & 155 \\
\hline \multirow{7}{*}{ Cote d'Ivoire } & Abidjan - Bamako & 1236 \\
\hline & Abidjan-Niamey & 1694 \\
\hline & Abidjan - Ouagadougou & 1232 \\
\hline & Abidjan-Tema & 561 \\
\hline & Abidjan-Lomé & 728 \\
\hline & Abidjan-Cotonou & 870 \\
\hline & Abidjan-Lagos & 955 \\
\hline \multirow{6}{*}{ Ghana } & Tema - Bamako & 1967 \\
\hline & Tema-Niamey & 1576 \\
\hline & Tema-Ouagadougou & 1057 \\
\hline & Tema-Lomé & 169 \\
\hline & Tema-Cotonou & 311 \\
\hline & Tema-Lagos & 436 \\
\hline \multirow{3}{*}{ Nigeria } & Lagos-Bamako & 1942 \\
\hline & Lagos - Niamey & 1028 \\
\hline & Lagos-Ouagadougou & 1095 \\
\hline \multirow{8}{*}{ Senegal } & Dakar-Bamako & 1053 \\
\hline & Dakar-Niamey & 2695 \\
\hline & Dakar-Ouagadougou & 2204 \\
\hline & Dakar -Tema & 2918 \\
\hline & Dakar -Lomé & 3135 \\
\hline & Dakar-Cotonou & 3194 \\
\hline & Dakar-Lagos & 3250 \\
\hline & Dakar-Abidjan & 2360 \\
\hline \multirow{3}{*}{ Togo } & Lomé - Bamako & 1973 \\
\hline & Lomé - Niamey & 1222 \\
\hline & Lomé - Ouagadougou & 928 \\
\hline \multicolumn{2}{|c|}{ Total (without overlaps) } & 46383 \\
\hline Countries & Corridors & Rail Distance $(\mathrm{km})$ \\
\hline Abidjan & Abidjan-Ouagadougou & 1260 \\
\hline Dakar & Dakar-Bamako & 1230 \\
\hline
\end{tabular}

Source: Researchers' Compilation from Sofreco and Nathan Associates (2011).

Note: Statistics is based on road length.

\section{$\underline{\text { Analysis of Total Transport Cost via Selected Transport Corridors }}$}

Total transportation cost can be represented mathematically as:

$T C=\sum_{n=1}^{k} d_{n} D_{n} F_{n}$ 
Where;

Dn = quantity in millions of tons

$d n=$ distance between two locations

$F n=$ transportation cost in ton kilometers

The model makes the assumption that the cost per ton kilometer for rail transport is utilized instead of road where direct rail transport from a port location to a market is available, as rail cost is cheaper in line with the cost minimization objective. Abidjan's rail distance to Bamako is longer than the road route. However, the transport cost per ton kilometer is cheaper and hence the total transport cost via the rail route is the cheaper option and is used in this analysis (See Tables 7-12).

Table 6. Scenario I - Suppose West African LLCs Choose Port of Abidjan

\begin{tabular}{|c|c|c|c|c|c|}
\hline Port & $\begin{array}{c}\text { Hinterland } \\
\text { Markets }\end{array}$ & $\begin{array}{c}\text { Distance } \\
(\mathrm{km})\end{array}$ & $\begin{array}{c}\text { Quantity } \\
(\text { million t.) }\end{array}$ & $\begin{array}{c}\text { Cost } \\
(\mathrm{US} \$ / \mathrm{km} . t o n)\end{array}$ & $\begin{array}{c}\text { Total cost } \\
(\mathrm{US} \$)\end{array}$ \\
\hline \multirow{2}{*}{$\begin{array}{c}\text { Abidjan } \\
\text { (Cote } \\
\text { d'Ivoire) }\end{array}$} & Bamako & 1236 & 7.31 & 0.17 & 1535.91 \\
\cline { 2 - 6 } & Niamey & 1694 & 5.72 & 0.17 & 1647.25 \\
\cline { 2 - 6 } & Ouagadougou* & 1232 & 6.90 & 0.14 & 1190.11 \\
\hline \multicolumn{7}{|c|}{ Total transport cost (million US\$) } \\
\hline
\end{tabular}

Source: Researchers 2018.

Table 7. Scenario II - Suppose West African LLCs Choose Port of Cotonou

\begin{tabular}{|c|c|c|c|c|c|}
\hline Port & $\begin{array}{c}\text { Hinterland } \\
\text { Markets }\end{array}$ & $\begin{array}{c}\text { Distance } \\
(\mathrm{km})\end{array}$ & $\begin{array}{c}\text { Quantity } \\
(\text { million } \mathrm{t})\end{array}$ & $\begin{array}{c}\text { Cost } \\
(\mathrm{US} \$ / \mathrm{km} . t \mathrm{ton})\end{array}$ & $\begin{array}{c}\text { Total cost } \\
(\mathrm{US} \$)\end{array}$ \\
\hline \multirow{2}{*}{$\begin{array}{c}\text { Cotonou } \\
\text { (Benin) }\end{array}$} & Bamako & 1947 & 7.31 & 0.18 & 2561.86 \\
\cline { 2 - 6 } & Niamey & 1070 & 5.72 & 0.18 & 1101.67 \\
\cline { 2 - 6 } & Ouagadougou & 1200 & 6.90 & 0.18 & 1490.40 \\
\hline \multicolumn{6}{|c|}{ Total transport cost (million US\$) } \\
\hline
\end{tabular}

Source: Researchers 2018.

Table 8. Scenario III - Suppose West African LLCs Choose Port of Dakar

\begin{tabular}{|c|c|c|c|c|c|}
\hline Port & $\begin{array}{c}\text { Hinterland } \\
\text { Markets }\end{array}$ & $\begin{array}{c}\text { Distance } \\
(\mathrm{km})\end{array}$ & $\begin{array}{c}\text { Quantity } \\
(\text { million } \mathrm{t})\end{array}$ & $\begin{array}{c}\text { Cost } \\
(\mathrm{US} \$ / \mathrm{km} . t o n)\end{array}$ & $\begin{array}{c}\text { Total cost } \\
(\mathrm{US} \$)\end{array}$ \\
\hline \multirow{2}{*}{$\begin{array}{c}\text { Dakar } \\
\text { (Senegal) }\end{array}$} & Bamako $*$ & 1053 & 7.31 & 0.18 & 1385.54 \\
\cline { 2 - 6 } & Niamey & 2695 & 5.72 & 0.21 & 3237.23 \\
\cline { 2 - 7 } & Ouagadougou & 2204 & 6.90 & 0.21 & 3193.60 \\
\hline \multicolumn{7}{|c|}{ Total transport cost (million US\$) } \\
\hline
\end{tabular}

Source: Researchers 2018.

Table 9. Scenario IV - Suppose West African LLC's Chose Port of Lagos (Apapa)

\begin{tabular}{|l|c|c|c|c|c|}
\hline \multicolumn{1}{|c|}{ Port } & $\begin{array}{c}\text { Hinterland } \\
\text { Markets }\end{array}$ & $\begin{array}{c}\text { Distance } \\
(\mathrm{km})\end{array}$ & $\begin{array}{c}\text { Quantity } \\
(\text { million } \mathrm{t})\end{array}$ & $\begin{array}{c}\text { Cost } \\
(\mathrm{US} \$ / \mathrm{km} . t o n)\end{array}$ & $\begin{array}{c}\text { Total cost } \\
(\mathrm{US} \$)\end{array}$ \\
\hline \multirow{2}{*}{$\begin{array}{l}\text { Lagos } \\
\text { (Nigeria) }\end{array}$} & Bamako & 1942 & 7.31 & 0.20 & 2839.20 \\
\cline { 2 - 6 } & Niamey & 1028 & 5.72 & 0.20 & 1176.03 \\
\cline { 2 - 6 } & Ouagadougou & 1095 & 6.90 & 0.20 & 1511.10 \\
\hline \multicolumn{5}{|c|}{ Total transport cost (million US\$) } \\
\hline
\end{tabular}

Source: Researchers 2018. 
Table 10. Scenario V-Suppose West African LLC's Chose Port of Lomé

\begin{tabular}{|l|c|c|c|c|c|}
\hline Port & $\begin{array}{c}\text { Hinterland } \\
\text { Markets }\end{array}$ & $\begin{array}{c}\text { Distance } \\
(\mathrm{km})\end{array}$ & $\begin{array}{c}\text { Quantity } \\
(\text { million } \mathrm{t})\end{array}$ & $\begin{array}{c}\text { Cost } \\
(\mathrm{US} \$ / \mathrm{km} . t \mathrm{n})\end{array}$ & $\begin{array}{c}\text { Total cost } \\
(\mathrm{US} \$)\end{array}$ \\
\hline \multirow{2}{*}{$\begin{array}{l}\text { Lomé } \\
(\text { Togo })\end{array}$} & Bamako & 1973 & 7.31 & 0.18 & 2596.07 \\
\cline { 2 - 6 } & Niamey & 1222 & 5.72 & 0.18 & 1258.17 \\
\cline { 2 - 6 } & Ouagadougou & 928 & 6.90 & 0.18 & 1152.58 \\
\hline \multicolumn{7}{|c|}{ Total transport cost (million US\$) } & 5006.82 \\
\hline
\end{tabular}

Source: Researchers (2018).

Table 11. Scenario VI-Suppose West African LLC's Chose Port of Tema

\begin{tabular}{|l|c|c|c|c|c|}
\hline Port & $\begin{array}{c}\text { Hinterland } \\
\text { Markets }\end{array}$ & $\begin{array}{c}\text { Distance } \\
(\mathrm{km})\end{array}$ & $\begin{array}{c}\text { Quantity } \\
(\text { million } \mathrm{t})\end{array}$ & $\begin{array}{c}\text { Cost } \\
(\mathrm{US} \$ \mathbf{k m} . t o n)\end{array}$ & $\begin{array}{c}\text { Total cost } \\
(\mathrm{US} \$)\end{array}$ \\
\hline \multirow{2}{*}{$\begin{array}{l}\text { Tema } \\
\text { (Ghana) }\end{array}$} & Bamako & 1967 & 7.31 & 0.16 & 2300.60 \\
\cline { 2 - 6 } & Niamey & 1576 & 5.72 & 0.16 & 1552.36 \\
\cline { 2 - 6 } & Ouagadougou & 1057 & 6.90 & 0.16 & 1166.93 \\
\hline \multicolumn{7}{|c|}{ Total transport cost (million US\$) } \\
\hline
\end{tabular}

Source: Researchers (2018).

From the analysis above, the total transport cost with regards to inland transport of goods from ports to markets range between US\$ 4,373.27 million for the port of Abidjan and US\$ 7, 816.37 million for the Port of Dakar. Additionally, the ranking pattern of the cheapest route based on the total inland transportation cost is shown in Figure 7.

Figure 7. Total Transport Cost for West African LLCs from Selected Transit Ports

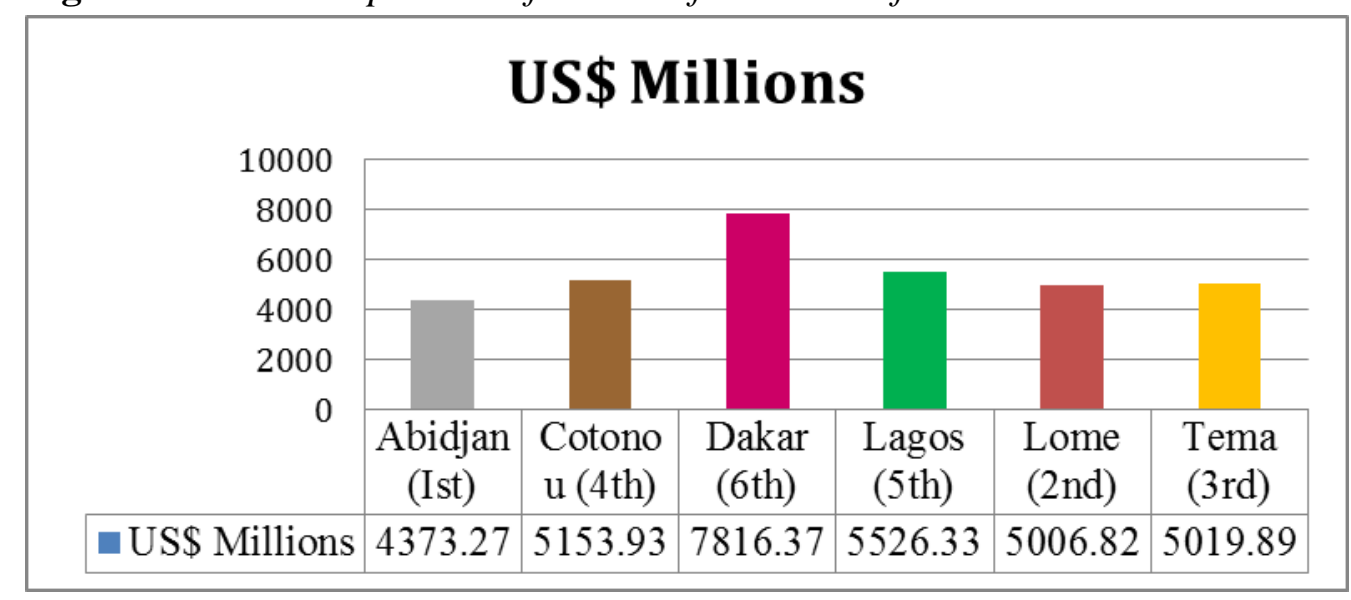

Analyzing Total Transport Cost with Forecasted Demand

A demand forecast for market regions is made, as dry port development should be based on expected demand of markets. The forecasted demand of the markets is based on multiple variables that include GDP, population and FDI of the countries in which the markets are located (see Table 13). 
Table 12. Economic Variables Used for Demand Forecast

\begin{tabular}{|c|c|c|c|c|c|c|c|c|c|c|c|}
\hline $\begin{array}{l}\text { GDP } \\
\text { US\$ mil }\end{array}$ & '06 & '07 & '08 & '09 & '10 & '11 & '12 & ' 13 & '14 & ' 15 & '16 \\
\hline Benin & 5142.1 & 5970.4 & 7133.8 & 7097.2 & 6970.5 & 7814.3 & 8117.6 & 9111.2 & 9575.0 & 9932.4 & 1064.5 \\
\hline${ }^{2}$ B. Faso & 5845.7 & 6991.7 & 8378.4 & 8369.5 & 8969.5 & 10724.6 & 11166.4 & 11947.6 & 12377.5 & 10419.7 & 11693.1 \\
\hline Cote d'Ivoire & 17801.3 & 20344.6 & 24255.6 & 24277.8 & 24885.3 & 25382.7 & 27041.5 & 31293.0 & 34242.6 & 36345.9 & 39101.5 \\
\hline Ghana & 20409.8 & 24759.5 & 28527.1 & 25978.4 & 32175.9 & 39566.2 & 41940.3 & 47805.6 & 38617.5 & 41764.8 & 45231.7 \\
\hline Mali & 6975.0 & 8146.3 & 9751.4 & 10181.7 & 10679.5 & 12978.7 & 12443.7 & 13246.9 & 14388.8 & 13176.8 & 14035.8 \\
\hline Niger & 3664.6 & 4291.9 & 5403.6 & 5397.6 & 5719.7 & 6409.6 & 6942.5 & 7668.5 & 8245.4 & 7143.6 & 7509.5 \\
\hline Nigeria & 145430.4 & 166451.8 & 208065.7 & 169481.3 & 369062.2 & 411744.0 & 460954.3 & 514965.9 & 568508.6 & 600125.3 & 649071.6 \\
\hline Senegal & 9359.1 & 11285.7 & 13386.0 & 12813.4 & 12932.2 & 14441.6 & 14046.3 & 14952.9 & 15658.5 & 17002.7 & 18657.5 \\
\hline Togo & 2203.6 & 2523.4 & 3163.0 & 3163.5 & 3173.3 & 3756.7 & 3916.4 & 4339.8 & 4518.1 & 6734.8 & 8465.9 \\
\hline
\end{tabular}




\begin{tabular}{|c|c|c|c|c|c|c|c|c|c|c|c|}
\hline $\begin{array}{l}\text { FDI } \\
\text { US\$ mill }\end{array}$ & ‘06 & '07 & '08 & ‘09 & ' 10 & '"11 & '12 & '13 & '14 & '15 & ‘'16 \\
\hline Benin & -12.4 & 139.0 & 48.0 & -18.7 & 53.5 & 161.1 & 281.6 & 360.2 & 377.4 & 380.2 & 385.9 \\
\hline B.Faso & 83.8 & 21.7 & 33.1 & 56.4 & 38.8 & 143.7 & 329.3 & 490.3 & 356.8 & 167.4 & 308.7 \\
\hline Cote d'Ivoire & 350.7 & 443.2 & 466.5 & 396.0 & 358.1 & 301.6 & 330.3 & 407.5 & 462.0 & 466.8 & 499.1 \\
\hline Ghana & 636.0 & 1383.2 & 2714.9 & 2372.5 & 2527.4 & 3247.6 & 3294.5 & 3227.0 & 3363.4 & 3501.0 & 3786.4 \\
\hline Mali & 148.2 & 206.1 & 266.4 & 646.6 & 371.6 & 556.1 & 397.9 & 307.9 & 144.0 & 275.4 & 125.5 \\
\hline Niger & 40.2 & 98.9 & 281.9 & 631.3 & 795.9 & 1066.5 & 841.3 & 719.1 & 821.9 & 529.3 & 292.8 \\
\hline Nigeria & 4854.4 & 6035.0 & 8196.6 & 8554.8 & 6026.2 & 8841.1 & 7069.9 & 5562.9 & 4655.8 & 4895.7 & 5001.3 \\
\hline Senegal & 289.6 & 351.0 & 453.9 & 330.1 & 266.1 & 338.2 & 276.2 & 311.3 & 342.7 & 378.4 & 390.0 \\
\hline Togo & 91.3 & 62.3 & 50.7 & 46.1 & 124.9 & 727.8 & 121.5 & 195.8 & 292.1 & 335.8 & 378.5 \\
\hline
\end{tabular}

\begin{tabular}{|c|c|c|c|c|c|c|c|c|c|c|c|}
\hline $\begin{array}{l}{ }^{3} \text { Pop } \\
\text { mil }\end{array}$ & ‘06 & '07 & ‘08 & ‘09 & '10 & '’11 & '12 & '13 & '14 & '15 & '16 \\
\hline Benin & 8.4 & 8.7 & 9.0 & 9.2 & 9.5 & 9.8 & 10.0 & 10.3 & 10.6 & 11.0 & 11.7 \\
\hline B.Faso & 13.8 & 14.2 & 14.7 & 15.1 & 15.6 & 16.1 & 16.6 & 17.1 & 17.6 & 18.1 & 18.6 \\
\hline Cote d'Ivoire & 18.5 & 18.9 & 19.3 & 19.7 & 20.1 & 20.6 & 21.1 & 21.6 & 22.2 & 22.5 & 23.0 \\
\hline Ghana & 22.0 & 22.5 & 23.1 & 23.7 & 24.3 & 24.9 & 25.5 & 26.2 & 26.8 & 27.6 & 28.3 \\
\hline Mali & 13.2 & 13.6 & 14.1 & 14.6 & 15.1 & 15.5 & 16.0 & 16.5 & 17.0 & 17.5 & 18.0 \\
\hline Niger & 14.1 & 14.7 & 15.2 & 15.8 & 16.4 & 17.1 & 17.7 & 18.4 & 19.1 & 19.9 & 20.7 \\
\hline Nigeria & 143.3 & 147.2 & 151.1 & 155.2 & 159.4 & 163.8 & 168.2 & 172.8 & 177.5 & 180.3 & 188.6 \\
\hline Senegal & 11.6 & 11.9 & 12.2 & 12.6 & 13.0 & 13.4 & 13.8 & 14.2 & 14.7 & 15.6 & 16.0 \\
\hline Togo & 5.7 & 5.9 & 6.1 & 6.2 & 6.4 & 6.6 & 6.7 & 6.9 & 7.1 & 7.7 & 8.4 \\
\hline
\end{tabular}

Source: Population, Foreign Direct Investment (Total Inflows), GDP (World Bank 2018).

${ }^{3}$ Population. 


\section{Linear Regression Model \& Application}

According to (Peng and Chu 2009), linear regression is one of the most common quantitative prediction methodologies and it has been extensively applied in port throughput literatures to ascertain indicators of throughput and forecast implementation. Tongzon (1995) and Tongzon and Wu (2005) employed linear regression to demonstrate the causal relationship between the determinants of cargo throughput and port performance. Seabrooke et al. (2003) also projected the level of cargo growth through the application of regression analysis techniques in Hong Kong. Additionally, a further study by (Chou et al. 2008) was conducted in projecting volumes of import containers in Taiwan where a modified regression model was developed to guarantee improved forecast accuracy. The prediction of throughput capacities has a substantial effect on port development strategy and the capacity to offer quality and effective services. Thus, a basic forecasting selection technique was adapted from Wang et al. (2009) (See Figure 8).

Figure 8. Common Quantitative Forecasting Methods

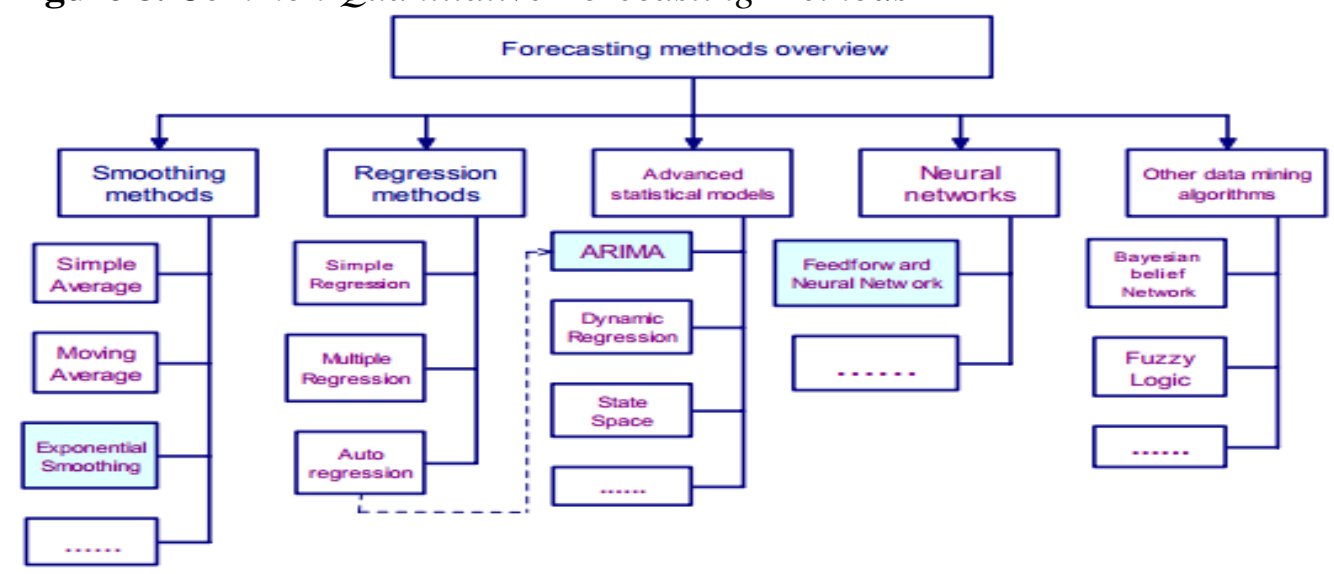

Source: Rule Induction for Forecasting Method Selection (Wang et al. 2014).

Sun (2010) suggested a dual forecasting model based on conditional expectation through probability dissemination of port cargo throughput. Alternatively, Huang et al. (2003) have applied the grey model in forecasting demand in a transportation network. An improved Grey theory using Fourier series FRMGM $(1,1)$ for enhancing forecast accuracy of cargo throughput at Kaohsiung ports from 2013-2015 has also been applied by (Wang and Phan 2014). In this study, forecasting cargo throughput for the West African LLCs is executed using a classical time-series regression model.

\section{$\underline{\text { Forecast Model and Analysis }}$}

In defining the economic indicators to be used in the regression model, numerous indicators were evaluated to check their level of correlation and the most remarkably used indicators in previous research include Population, Gross Domestic Product (GDP), Foreign Direct Investment (FDI) inflows and the level of imports and exports. The economic data used in the regression 
model is based on the hypothesis that these drivers are the key factors of cargo throughput for West African LLCs.

$\mathrm{Y}=\mathrm{A}+\mathrm{B}_{1} \mathrm{X}_{1}+\mathrm{B}_{2} \mathrm{X}_{2}+\ldots \mathrm{BnXn}$

Where:

$\mathrm{Y}=$ dependent variable (container throughput)

$\mathrm{Xn}=$ independent variable

$\mathrm{a}=\mathrm{y}$ - intercept (value of $\mathrm{y}$ when $\mathrm{x}=0$ )

$b=$ slope or trend

$\mathrm{b}=\frac{\mathrm{N} \sum \mathrm{XY}-\sum \mathrm{X} \sum \mathrm{Y}}{\mathrm{N} \sum \mathrm{X}^{2}-\left(\sum \mathrm{X}\right)^{2}} \quad \mathrm{a}=\frac{\sum \mathrm{Y}}{\mathrm{N}}-\mathrm{b}\left(\frac{\sum \mathrm{X}}{\mathrm{N}}\right)$

Where $\mathrm{N}=$ number of period of data

The accuracy of the regression model was first checked by looking at the $\mathrm{R}$ square and adjusted $\mathrm{R}$ square figures from the output of the regression statistics. The $\mathrm{R}$ square values were verified to ensure that the variance of the output variable (cargo throughput) can be clarified by the variance of the input variables (GDP FDI and population). The adjusted $\mathrm{R}$ square, which is a more conservative form of the $\mathrm{R}$ square, was also verified and this indicates the model is very consistent for forecasting future cargo throughput levels. The coefficient, GDP and FDI were therefore found to be statistically significant at level that were much lower than 0.05. Cargo throughput, GDP and FDI are set respectively as, $Y$ and $\mathrm{X} 1$ and $\mathrm{X} 2$ respectively in the model and based on the output. Deriving the expected GDP forecast and FDI forecast for the next period (2017) is required in order to derive the throughput for the next period and this is achieved by determining the GDP and FDI value depending on time $(t)$ using a linear equation. In order to obtain the linear equation in the form $\boldsymbol{x} \mathbf{I t}$ $\boldsymbol{=} \boldsymbol{a}+\boldsymbol{b} . \boldsymbol{t}$, (where $x l t$ is the anticipated GDP forecast) and determine the coefficients $b$ and $a$, the values for $t 2$ and $x l * t$ need to be determined. The result of the forecasted data is presented Table 14 below. 
Table 13. Forecasted Demand of Economic Variables for West African LLCs

\begin{tabular}{|c|c|c|c|c|c|c|c|}
\hline${ }^{4}$ LLCs & $' 17$ & $' 18$ & $' 19$ & $' 20$ & ${ }^{\prime} 21$ & $' 22$ & $' 23$ \\
\hline Benin & 8.82 & 9.40 & 9.93 & 10.51 & 10.97 & $11 . .49$ & 11.98 \\
\hline Burkina-Faso & 7.64 & 8.23 & 8.72 & 9.41 & 9.89 & 10.38 & 10.91 \\
\hline Cote d'Ivoire & 16.89 & 17.49 & 17.93 & 18.38 & 19.58 & 19.99 & 20.61 \\
\hline Ghana & 12.30 & 12.84 & 13.41 & 13.98 & 14.52 & 14.99 & 15.45 \\
\hline Mali & 7.95 & 8.68 & 9.02 & 9.78 & 10.44 & 10.97 & 11.63 \\
\hline Niger & 6.39 & 6.82 & 7.30 & 7.81 & 8.20 & 8.69 & 9.01 \\
\hline Nigeria & 21.67 & 22.32 & 22.86 & 23.41 & 23.94 & 24.49 & 24.98 \\
\hline Senegal & 10.72 & 11.41 & 11.98 & 12.49 & 12.97 & 13.43 & 13.96 \\
\hline Togo & 9.01 & 9.62 & 10.20 & 10.74 & 11.27 & 11.70 & 12.41 \\
\hline Total & 34.28 & 36.59 & 38.45 & 40.98 & 43.05 & 45.03 & 47.01 \\
\hline
\end{tabular}

Source: Researchers 2018.

From the year 2017-2023, a combined forecasted cargo throughput of 285.39 million tonnes of cargoes shall be loaded and discharged through port of Abidjan and cargo throughput has increased at an average of $9 \%$ per annum.

\section{Port of Abidjan as a Gateway Port to West African Landlocked Countries}

The Port of Abidjan is located in the economic capital of the Cote d'Ivoire, West Africa's largest French-speaking nation. It is one of the largest sea ports in West Africa lying on the Ebire Lagoon N $05^{\circ} .3$ and $\mathrm{E}-4.0^{\circ}$ connecting the Atlantic by the Vridi Channel. The port is located at the intersection of major shipping lines from U.S.A, Europe and Asia. It is one of the region's shipping hubs with a land surface area of 8,000 $000 \mathrm{~m} 2$ housing 36 conventional berths located along its three main quays (Eastern, Southern and Northern Quays). Although the port has recently lost most of its market to neighboring competitors such as Tema, Lomé and Dakar due to the sporadic post electoral crisis in 2011, it still receives an average of 5217 vessels 2017, comprising of general cargo vessels, tankers, RoRo, container vessels etc. and this implies that the port of Abidjan is expected to regain stability in the nearest future.

Recently, the port of Abidjan has expanded by building new terminals, upgraded its IT systems as well as widened its operational partnerships and networks in order to revive its port sector. This is reflected by the port's ability to handle increasing volumes of traffic from 19.6 million tonnes in 2016 to 20.2 million tonnes in 2017 (See Figure 9). Development projects completed in 2020 shall include expansion and dredging of the Vridi access channel, construction of a second container terminal, modernization of the fishing berth, installation of conveyor belt for cement and clinker vessels etc. Additionally, the Port of Abidjan generally runs a variety of the landlord port management system and the port authority is responsible for regulating port operations, in addition to building and maintaining infrastructures.

${ }^{4}$ LLCs- Land Locked Countries. 
Figure 9. Port of Abidjan Transit Traffic Statistics by Destination 2008 - 2017

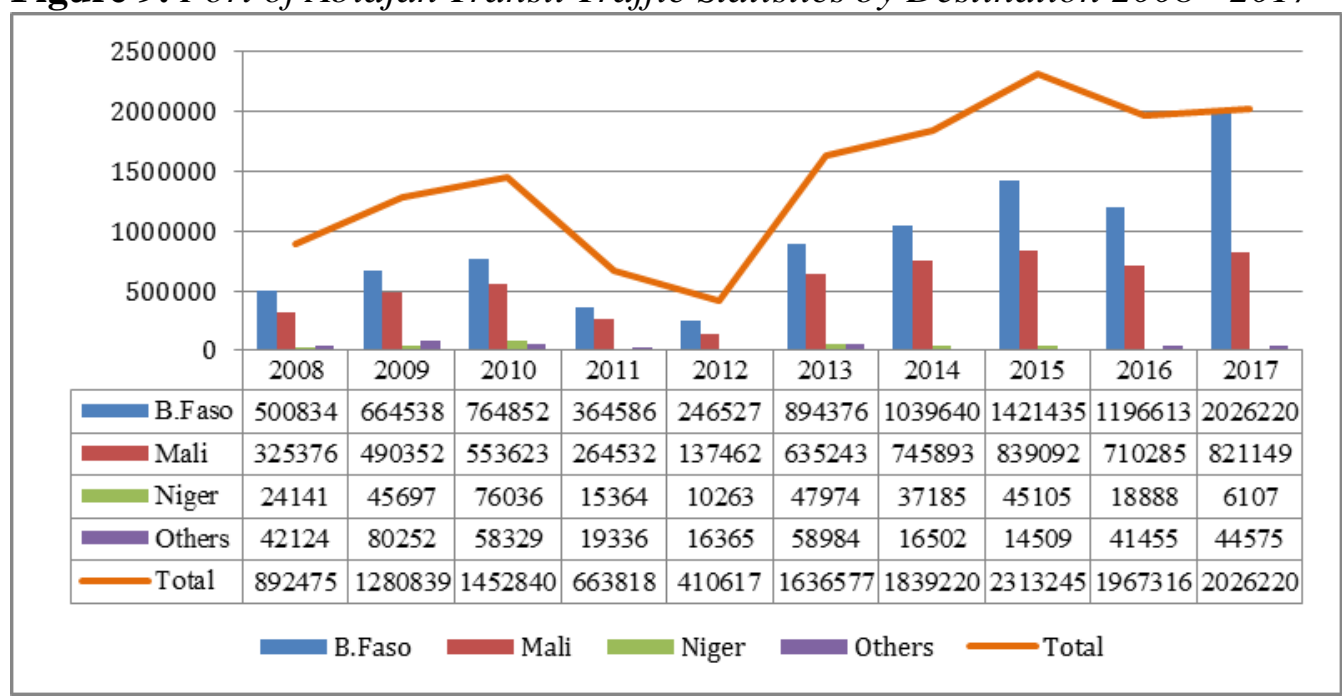

Source: Researcher's compilation from the port website (www.portabidjan.com).

\section{Inland/Dry Port Location Selection}

The gravity location model is used in this section to propose an optimum location of a dry port for the region with the Port of Abidjan as a gateway port. This is proposed in order to take further advantage of scale economies and increase the level of service for efficient distribution of cargo to hinterland markets in West Africa. The model is basically used in management science to determine the optimum location of a facility that has the function of either reducing transit time or lowering transport cost. The cost of distribution is seen as a linear function of the distance and the quantity or weight of cargo transported. The model uses a coordinate system superimposed on a visual map with the coordinates representing a set of numerical values when calculating averages. The grid map set up on a Cartesian plane identifies a set of coordinates which designates a location central to all other locations on the grid map. Using a map of West Africa, geometric locations of port and market are ascertained using $X$ and $Y$ axes.

The coordinates for the location of the dry port facility are computed using the following formula:

$$
x=\frac{\sum_{i=1}^{n} x_{i} w_{i}}{\sum_{i=1}^{n} w_{i}} y=\frac{\sum_{i=1}^{n} y_{i} w_{i}}{\sum_{i=1}^{n} w_{i}}
$$

Where,

$x, y=$ coordinates of the dry port facility at the center of gravity $x i, y i=$ coordinates of gateway port and other competitive ports $W i=$ annual demand shipped from gateway port to a particular market 
In the Euclidean plane, the distance between two points is derived using a formula equivalent to the Pythagorean Theorem. Therefore, the distances between the regional hub port and markets are calculated using the formula:

$d_{\mathrm{n}}=\sqrt{\left(x-x_{\mathrm{n}}\right)^{2}+\left(y-y_{\mathrm{n}}\right)^{2}}$

Where,

$x n, y n=$ coordinate location of either a market or supply source (gateway port) $F n=$ cost of transporting one unit for one kilometer between the gateway port and market

$d n=$ distance between the gateway port and the market $n$.

For this particular study, Euclidean distances are not used as real road distances from sources to markets are available. Euclidean distances do not show the real situation on the ground as such direct lines as measures of distance are more suited to air travel than road transport. It is quite unusual for roads leading from one point to another to be ultimately a straight line. Therefore, real distances will portray a more accurate picture and result in a more accurate outcome in determining a dry port location for consolidation and distribution of cargo as indicated on Figure 10 and Table 5.

Figure 10. Grid Map of Regional Hub Port and Markets

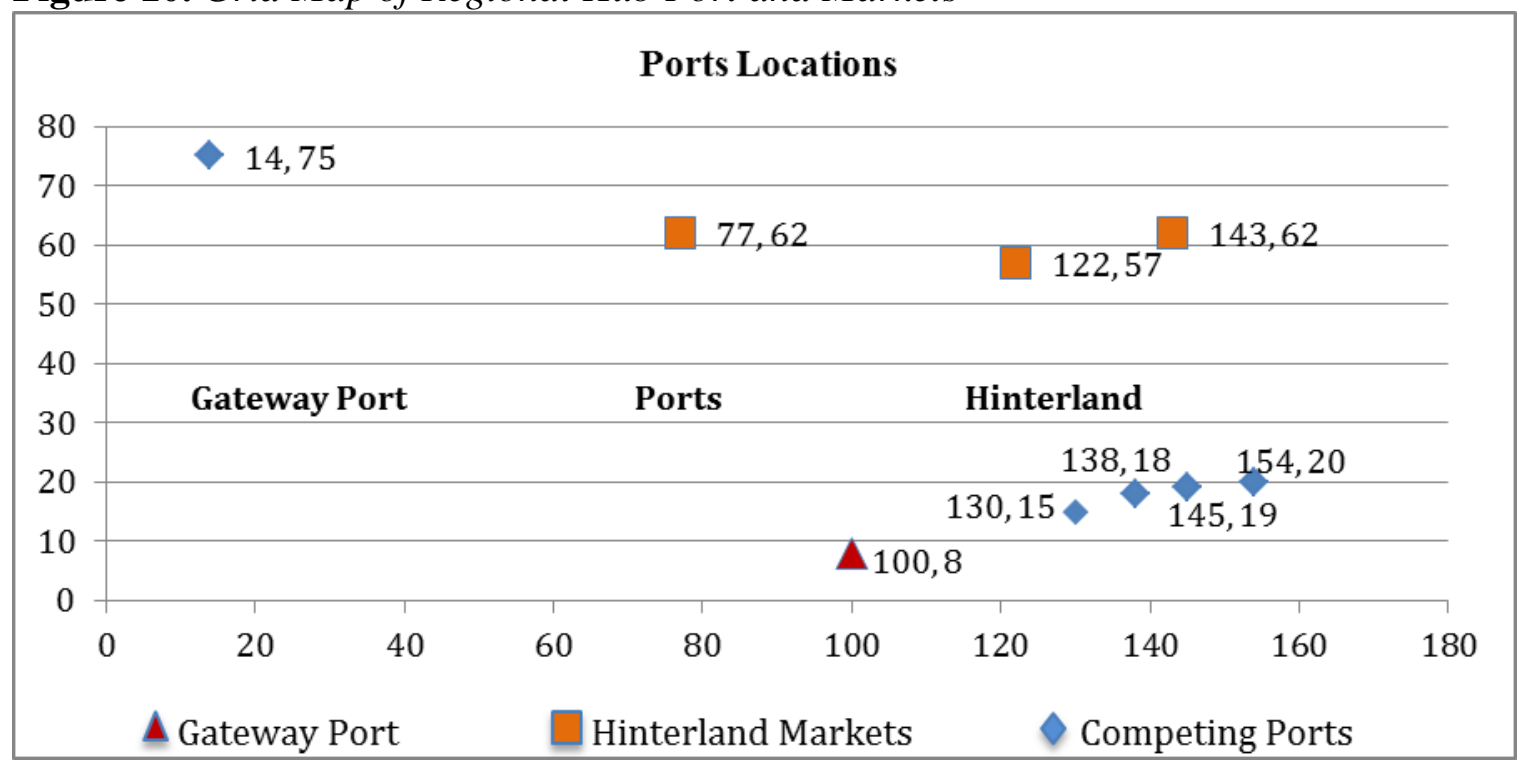

Source: Researchers 2018. 
Table 14. Derivation of Gravity Center

\begin{tabular}{|c|c|c|c|c|c|c|c|c|c|}
\hline \multirow{2}{*}{$\begin{array}{l}\text { Source/ } \\
\text { Markets }\end{array}$} & \multirow{2}{*}{$\begin{array}{c}\text { \$/Ton } \\
\mathrm{Km} \\
\left(\mathrm{f}_{\mathrm{n}}\right)\end{array}$} & \multirow{2}{*}{$\begin{array}{c}\text { mTons } \\
D_{n}\end{array}$} & \multirow{2}{*}{$\begin{array}{c}\mathrm{Fi} \\
\$ / \mathrm{km}\end{array}$} & \multicolumn{2}{|c|}{ Coordinates } & \multirow{2}{*}{$\begin{array}{c}\text { Distance } \\
d_{n}\end{array}$} & \multirow{2}{*}{$\begin{array}{c}\mathrm{D}_{\mathrm{n}} \mathrm{F}_{\mathrm{n}} \mathrm{x}_{\mathrm{n}} \\
/ \mathrm{d}_{\mathrm{n}}\end{array}$} & \multirow{2}{*}{ 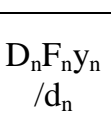 } & \multirow{2}{*}{$\begin{array}{c}\mathrm{D}_{\mathrm{n}} \mathrm{F}_{\mathrm{n}} \\
/ \mathrm{d}_{\mathrm{n}}\end{array}$} \\
\hline & & & & $\mathrm{y}_{\mathrm{n}}$ & $\mathrm{x}_{\mathrm{n}}$ & & & & \\
\hline Abidjan* & 0.17 & 19.58 & 3.33 & 100 & 8 & 25 & 13.314 & 1.065 & 0.133 \\
\hline Accra (Tema) & 0.17 & 14.52 & 2.47 & 130 & 13 & 561 & 0.572 & 0.057 & 0.004 \\
\hline Bamako & 0.17 & 10.44 & 1.78 & 77 & 62 & 1236 & 0.111 & 0.089 & 0.001 \\
\hline Cotonou & 0.17 & 10.97 & 1.86 & 138 & 19 & 870 & 0.296 & 0.041 & 0.002 \\
\hline Dakar & 0.17 & 12.97 & 2.20 & 14 & 75 & 2360 & 0.013 & 0.070 & 0.000 \\
\hline Lagos & 0.17 & 23.94 & 4.07 & 154 & 23 & 955 & 0.656 & 0.129 & 0.004 \\
\hline Lomé & 0.17 & 11.27 & 1,92 & 130 & 19 & 728 & 0.324 & 0.050 & 0.002 \\
\hline Niamey & 0.17 & 8.20 & 1.56 & 143 & 62 & 1694 & 0.118 & 0.051 & 0.000 \\
\hline Ouagadougou & 0.17 & 9.89 & 1.68 & 122 & 57 & 1232 & 0.166 & 0.078 & 0.001 \\
\hline & & & & & & & 15.570 & 1.630 & 0.148 \\
\hline
\end{tabular}

Source: Researchers 2018.

The resulting dry port location can be obtained by:

$X$ coordinate $=15.570 / 0.17=92.0 Y$ coordinate $=1.630 / 0.17=10.0$

Dry port can be located at point $(92,11)$ on the grid map.

Figure 11. Dry Port Location on Grid Map

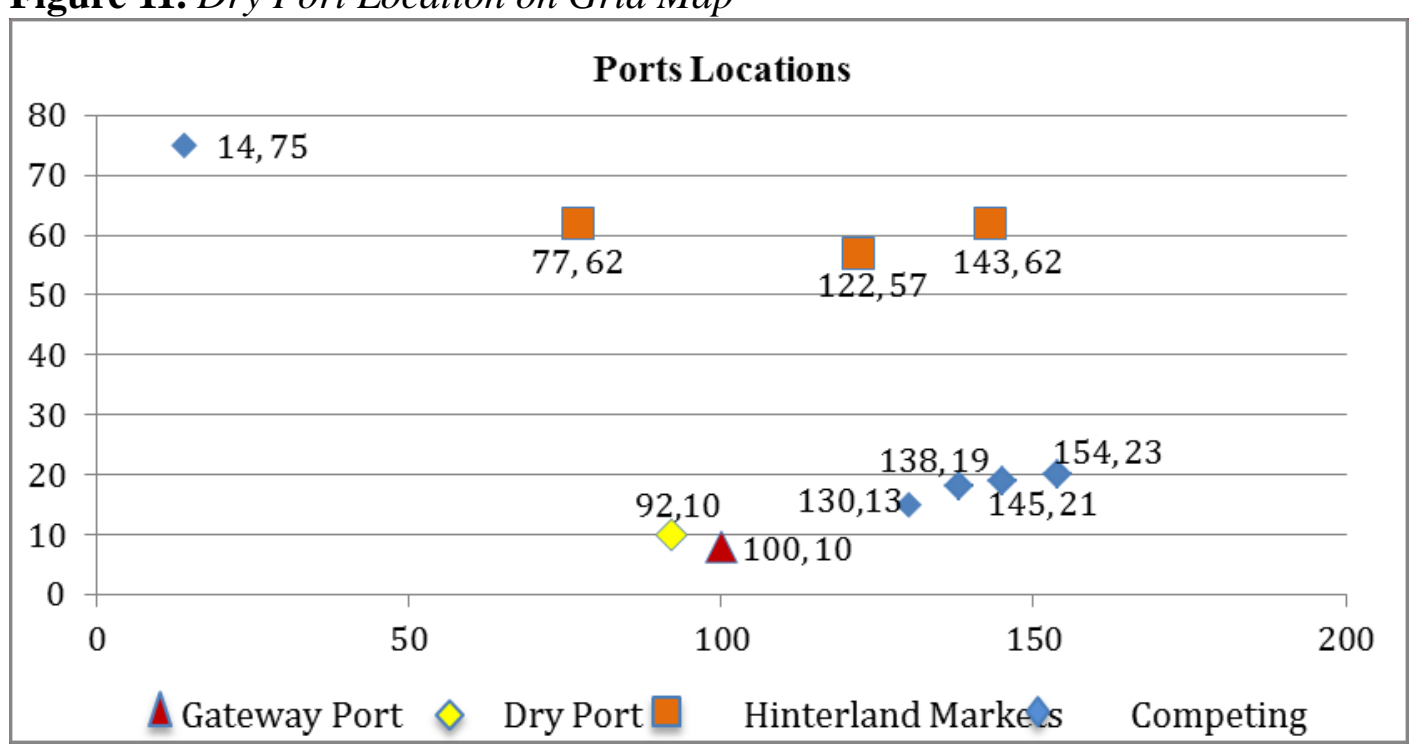

Source: Researchers 2018. 
Figure 12. Visual Map View of West African Cargo Distribution

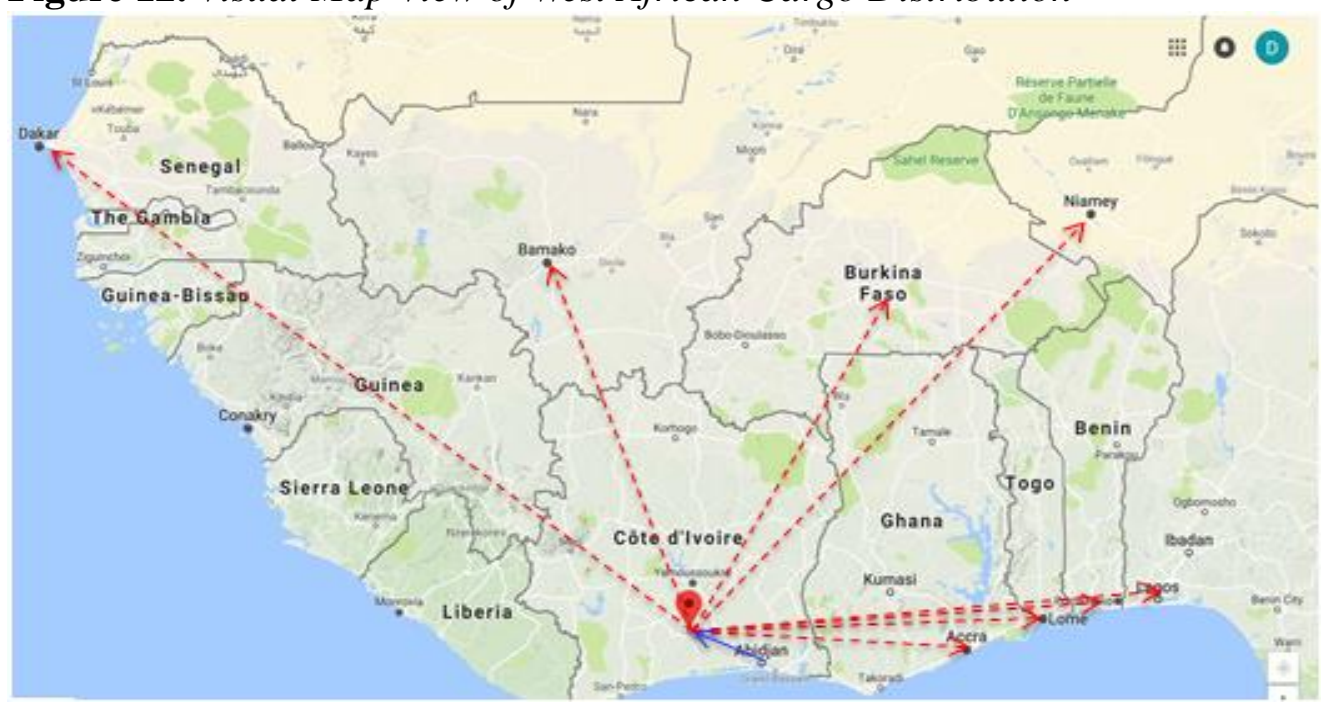

Source: Researchers 2018.

By superimposing the grid map (Figure 11) on the visual map (Figure 12), the optimum location for developing a regional dry port is a southern city in Cote d'Ivoire known as Divo. Divo is ranked the tenth most populated city in Cote d'Ivoire and a major advantage of this location is that it is connected to the port of Abidjan and other major cities within the country through the A2 highway. Transit cargo distribution from the regional hub port of Abidjan (Figure 12) would be transported to a dry port in Divo before an onward distribution to the various hinterland markets and commercial center within West Africa. This system would also decongest the port of Abidjan and enhance its productivity. Additionally, the Abidjan-Ouagadougou corridor remains a pivot transport framework for cargo destined for Burkina-Faso (Northbound and Southbound) via rail service as this may offset additional handling and facilitation costs that may arise from the utilization of the dry port. Also, direct shipments may leave the Port of Abidjan to the Dakar also due to distance constraints.

\section{Findings}

\section{SWOT for Developing Dry Port Cote d'Ivoire}

SWOT analysis is a corporate professional analytic technique applied by various institutions to assess their products and or services as well as the market situation when deciding the best way to attain a constant future growth. In the academic settings, numerous scholars have employed the SWOT as a major research methodology in undertaking their study and we refer readers with interest to Chen and Wang (2012), Augustin et al. (2018), Garnwa et al. (2009) and Wang (2011). 
Strengths

- Existence of Railway Network to Hinterland Markets: The existing rail network along Abidjan-Ouagadougou corridor has made it the busiest corridor due to volume of cargo transported. Transportation cost is of essence to shippers in West African hinterland markets thus, most cargoes are transported via the port of Abidjan by train in order to minimize cost and this in return has made the port of Abidjan more competitive over other seaports in the region.

- Port Expansion Projects and Dredging of Vridi Channel: Ports in West African region have all embarked on enormous port expansion projects and the Port of Abidjan is not an exception. Additionally, the size of the Vridi channel has been a major limitation to the size of vessels calling the port of Abidjan therefore; its expansion will enable larger vessels calling at the port as well as increase the port's annual throughput.

- Member of the same Regional Block with West African LLC's: Cote d'Ivoire is an active member of the same regional block (West African Economic Monetary Union) with the three West African Landlord countries using a common language with relatively stable currency (franc CFA).

- Strategic Location as a Gateway Port for West African Hinterland Markets: The geographical position of the port of Abidjan has made its port and corridor accessible to all West African hinterland markets in relation to distance and this marginal adjustment from Abidjan to the hinterland market illustrates how strategically located Cote d'Ivoire has been for transit traffic to its landlocked neighbors (Burkina-Faso, Mali \& Niger).

\section{Weaknesses}

- Political Instability coupled with Ethnic and Regional Tensions: A major weakness that has been a drawback for Cote d'Ivoire is the recent political crises and ethnic tensions which have saddled the country's economic sector and this has led to investors leaving the country to other neighboring West African nations.

- Limited Terminal Capacity: Most ports in the region are confronted with this problem thus, majority of them have embarked on massive port expansion projects. In response to this issue, the port of Abidjan has been concession to the French industrial conglomerate Bolloré so as to cater for the acute shortage of terminal needed for container handling operations at the port.

- Poor State of Trucks applying Abidjan-Ouagadougou Corridor: According to shippers from West African hinterland markets, trucks applying Abidjan - Ouagadougou corridor are currently in poor states thus, they are always confronted with constant breakdowns while in transit and this in return affects shippers lead time and competitiveness within the region. 


\section{Opportunities}

- Establishment of a Joint Border Post (JPB) with Landlocked Countries: The establishment of JPB with Burkina-Faso and Mali will create a unique platform where information can be shared between the customs systems of all parties thus, harmonizing the clearance procedure and reducing truck waiting time at the border. An example is the existing Joint Border Post between Togo and Burkina-Faso at Cinkassé.

- Efforts from Regional Blocks (ECOWAS \& UEMOA) to Promote Transit Traffic: West African regional bodies are making frantic efforts to ratify sustainable legislations that would promote intra-regional transit traffic. These legislations are aimed towards synchronizing and universalization of customs clearing procedures, insurance policies and transport frameworks between member states.

- Encourage Public Private Partnership (PPP) in the Port Sector: The participation of private entities in the Ivorian port sector is also a unique strategy that can be implemented by the port authority to boost productivity. The recent political crises has left the economy with very few foreign investors thus, deregulation of policies and privatization could help revamp its ports industry.

\section{Threats}

- Growing Ports Competition among Competitors: There is a continuous growing competition among ports located within the West African region and from competing neighboring corridors that are also part of same regional block (WAEMU) as Cote d'Ivoire. These corridor states include; Lomé-Ouagadougou, Dakar-Bamako and Cotonou-Ouagadougou. For example; Lomé-Ouagadougou transit corridor measures $928 \mathrm{~km}$ and is currently the shortest distance to the West African hinterland markets. Additionally, there is also an existing rail network to between DakarBamako transit corridor.

- Burkina-Faso as a Second Transit Nation for Niger: Burkina-Faso as a second transit state remains an inevitable bottleneck for shippers in Niger. Although Burkina-Faso is ranked $81^{\text {st }}$ position on the 2016 global LPI, its customs procedure is known to be sagged with lengthy documentation process and illegal extortion of fees from commuters transiting through its territory.

- Recent Pirate Attacks on Ships along the Gulf of Guinea: Recent attacks along the West African maritime territory have raised major concerns from shipping lines calling various ports along the coast and countries mostly affected in the region include; Benin republic, Ghana, Nigeria and Togo with 11 attacks in the first quarter of 2013 (IMB 2015). 


\section{Discussion}

The hinterland transport cost analysis conducted indicates that only few West African coastal countries offer cheap transit cost to shippers in hinterland markets and this has remained a major factor impeding the competiveness of landlocked countries with the global market in terms of international trade. Thus, there is an urgent need for stakeholders to implement measures that can reduce the transport cost and improve swift transportation of transit traffic along various transit corridors in West Africa. Adequate policies regarding the road-worthiness of trucks should also be implemented in order to reduce the number of damaged trucks on the corridor. The simple forecast conducted in this research indicates that the annual throughput for the port of Abidjan is going to experience a steady increase in the nearest future therefore, measures which could relieve the port during over capacity situations are instantly needed. Additionally, digitalizing most of the port's documentation systems will also reduce cargo clearance procedure at the port and at the various nodes along the corridor. Finally, there is a need to establish a joint regional force to protect West African maritime territories from pirate attacks and to ensure the safety and security of both vessels and cargoes calling at West African ports as this is a reliable measure to assure various shipping line the reasons for maritime businesses.

\section{Conclusions}

The Abidjan-Ouagadougou transit corridor is the only national transport network in Cote d'Ivoire that expedites cargoes designated for West African hinterland countries and it is also the principal route on the Ivorian territory that generates substantial revenue for the government. Thus, there is a need for the government to enhance an efficient and effective flow of transit traffic along the corridor. Additionally, the port of Abidjan is currently witnessing a tremendous development in port infrastructure due to its concession and this is coupled with a steadfast growth in the West African regional economy giving rise to a constant increasing demand for transport services. Hence, the development of a dry pot in Divo (Loh Djiboua district) remains a pilot program to promoting regional trade and sustainable transit traffic in Cote d'Ivoire and SubSaharan Africa. 


\section{References}

African Development Bank - AFDB (2010) Growing Forward: Developing Regional Hubs in Africa. Retrieved from https://bit.ly/2Id6IR5.

African Development Bank - AFDB (2015) Economic Transformation. Retrieved from https://bit.ly/2IOEUjk.

Arnold J (2005) Best Practice in Management of International Trade Corridor. Washington, DC: World Bank. Retrieved from: https://bit.ly/2OCLjp1.

Arvis JF, Ojala L, Shephard B, Saslavky D, Busch C, Raj A (2014) Connecting to Compete 2014: Trade Logistics in the Global Economy, the Logistics Performance Index and its Indicators. Washington, DC: World Bank.

Augustin DS, Akossiwa DL (2018) SWOT Analysis for Developing Dry Port in Togo. American Journal of Industrial and Business Management 8(6): 1407-1417.

Caballini C, Gattorna E (2009) The Expansion of the Port of Genoa: The Rivalta Scrivia Dry Port. Transport and Communications Bulletin for Asia and the Pacific 78: 103-125.

Chen JH, Wang Y (2012) SWOT-PEST Analysis in China's Dry Port. Advance Materials Research 479-481(Feb): 1004-1012.

Chou CC, Chu CW, Liang GS (2008) A Modified Regression Model for Forecasting the Volumes of Taiwan's Import Containers. Mathematical and Computer Modelling 47(9-10): 797-807.

Consumer News and Business Channel - CNBC Africa (2017). http://www.cnbcafri ca.com/.

Danida-Saana Consulting (2015) Accelerating Trade in West Africa-ATWA. Retrieved from: https://bit.ly/2yF1N5m.

Debrie J (2012) The West African Port System: Global Integration and Regional Particularities. Retrieved from EchoGéo: https://bit.ly/2G2XMMK.

Garnwa P, Baredford A, Pettit S (2009) Dry Ports: A Comparative Study of the United Kingdom and Nigeria. Transport and Communications Bulletin for Asia and the Pacific 78: 58-81.

Huang W, Wu S, Cheng P, Yu Z (2003) Application of Grey Theory to the Transport Demand Forecast from the Viewpoint of Life Cycle-Example for the Container Port in Taiwan. Journal of Maritime Sciences 12: 171-185.

International Maritime Bureau - IMB (2015) Piracy and Armed Robbery against Ships.

Kunaka C, Carruthers R (2014) Trade and Transport Corridor Management Toolkit. World Bank Training. Washington, DC: World Bank. Retrieved from: https://bit.ly/2ME1Pm6.

Liu Q (2010) Efficiency Analysis of Container Ports and Terminals. PhD Thesis. UK: Centre for Transport Studies, University College of London.

Maloni M, Jackson EC (2005) North American Container Port Capacity: An Exploratory Analysis. Transportation Journal 44(3): 1-22.

N'Guessan (2003) Improvement of Transit Transport in West Africa. https//unctad. org/en/Docs/ldc20032_en.pdf.

Nguyen CL, Notteboom T (2016) Dry Ports as Extensions of Maritime Deep-Sea Ports: A Case Study of Vietnam. Journal of International Logistics and Trade 14(1): 65-88.

Peng WY, Chu CW (2009) A Comparison of Univariate Methods for Forecasting Container Throughput Volumes. Mathematical and Computer Modelling 50(7-8): 1045-1057. 
Port Management Association for West and Central Africa - PMAWCA (2017) Accessed [January 21, 2014]. Retrieved from https://bit.ly/2FOzq80.

Roso V (2005) The Dry Port Concept Applications in Sweden. Proceedings of Logistics Research Network. Plymouth: International Logistics and Supply Chain Management.

Roso V, Woxenius J, Lumsden K (2009) The Dry Port Concept: Connecting Container Seaports with the Hinterland. Journal of Transport Geography 17(5): 338-345.

Seabrooke W, Hui E, Lam WA (2003) Forecasting Cargo Growth and Regional Role of Port of Hong Kong. Cities 20(1): 51-64.

Song DW, Cullinane K (1999) The Stochastic Frontier Model: A New Approach to Efficiency Measurement in Logistics Chains. Proceeding of the Universities Transport Group (UTSG) York, UK: University of York.

Sun L (2010) Research on a Double Forecasting Model for Port Cargo Throughput. World Journal of Modelling and Simulation 6(1): 57-62.

Tongzon J (1995) Determinants of Port Performance and Efficiency. Transport Research A 29(3): 245-352.

Tongzon J, Wu H (2005) Port Privatization, Efficiency and Competitiveness: Some Empirical Evidence from Container Ports (Terminals). Transportation Research Part A 39(2005): 405-424.

Torres C, van Seters J (2016) Overview of Trade and Barriers to Trade in West Africa. Discussion Paper 195. Maastricht: ECDPM

UNCLOS (1982) United Nations Convention on the Law of the Sea. Geneva, Switzerland. Retrieved from: https://bit.ly/1dSph2X.

UNESCAP (2012) Introduction to the Development of Dry Ports in Asia. Retrieved from: https://bit.ly/2TZAv21.

Veenstra A, Zuidwijk R, Asperen E (2012) The Extended Gate Concept of Container Terminals: Expanding the Notion of Dry Ports. Maritime Economics \& Logistics 14(1): 14-32.

Wang M (2011) Analysis of SWOT for the Development of Dry Port in Wuyishan. Journal of Wuyi University 4.

Wang X, Smith-Miles K, Hyndman R (2009) Rule Induction for Forecasting Method Selection: Meta-Learning the Characteristics of Univariate Time Series. Neurocomputing 72(10-12): 2581-2594.

Wang CN, Phan VT (2014) An Improvement in the Accuracy of Grey Forecasting Model for Cargo throughput in International Commercial Ports of Kaohsuing. WSEAS Transactions on Business and Economics 11(1): 322-327.

Woxenius J, Roso V, Lunsden K (2004) The Dry Port Concept- Connecting Seaports with their Hinterland by Rail, 305-319. Proceedings of ICLSP 2004. Retrieved from: https://bit.ly/2HZoEPO. 